\title{
Türk Eğitim Sistemindeki Mesleki Güvence Uygulamalarının Okula ve Ögrretmenlerin Performansına Etkisi
}

\author{
Arzu Engür \\ Antalya Milli Eğitim Müdürlüğü-Türkiye \\ arzuengur@hotmail.com
}

\author{
Prof. Dr. Kemal Kayıkçı \\ Akdeniz Üniversitesi-Türkiye \\ kemalkayikci@akdeniz.edu.tr
}

\begin{abstract}
Özet:
Güvence ilkesi insan kaynakları yönetiminin önemli ilkelerinden biridir. Güvence, iş güvencesi ve makam güvencesi olarak ikiye ayrlmaktadır. Iş güvencesi, bireyin haklı nedenler olmadan işten atılamaması anlamına gelmektedir. Iş güvencesi, iş doyumu, moral ve performans kavramlarının birbirini etkiledikleri söylenebilir. Bu çalışma temel olarak, farklı disiplinlerce ele alınan iş güvencesi kavramının sosyal ve psikolojik boyutlarının çalışanlar ve örgütleri üzerindeki etkilerini insan kaynakları yönetimi bakış açısıyla ele almayı amaçlamıştır. Araştırmada nitel araştırma yöntemi kullanılmıştır. Nitel araştırma yöntemlerinden olgubilim çalışması ile desenlenen araştırmada veriler yarı yapılandırımış görüşme formu ile toplanarak içerik analizi tekniği ile analiz edilmiştir. Araştırma öğretmenlere göre işin niteliğinin mesleki güvence ile değil, kişinin sahip olduğu iş ahlakı ile ilgili olduğu düşünülmekle birlikte mesleki güvencenin olması gerektiği, mesleki güvencenin olmamasının psikolojik baskı yaratacağı, mesleki güvencenin sağlıklı performans değerlendirmesi ile birlikte olması gerektiği, mesleki güvencenin kaygıyı azalttığı ve çalışanların barış ve huzur ortamında çalışmasına katkıda bulunduğu belirlenmiştir. Buna karşın aşırı ve koşulsuz iş güvencesinin örgütte işin niteliğini düşürdügü, kurumda monotonluğu ve çalışanda tükenmişlik hissini artırdığı, çalışanda kaygısızlığa yol açtığı anlaşılmıştır. Performans bilincinin oluşturulması eğitim çalışmalarına ihtiyaç olduğu, performans değerlendirmesinin uzman kadro ile adaletli, objektif bir şekilde çoklu kriterlere dayalı olarak yapılması gerektiği anlaşılmaktadır.
\end{abstract}

Keywords: Öğretmen, insan kaynakları, performans, mesleki güvence,

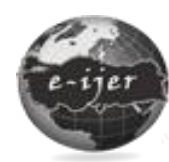

E-Uluslararası Eğitim

Araştırmaları Dergisi, Cilt: 11, Sayt: 2, 2020, ss. 16-34

DOI: 10.19160/ijer.735585

Gönderim : 2020-05-11 Kabul : 2020-09-04

\section{Önerilen Atıf}

Engür, A. \&. Kayıkçı, K. (2020). Türk Eğitim Sistemindeki Mesleki Güvence Uygulamalarının Okula ve Öğretmenlerin Performansına Etkisi, E-Uluslararası Eğitim Araştırmaları Dergisi, Cilt: 11, Sayı: 2, 2020, ss. 16-34, DOI: 10.19160/ijer.735585 


\section{Giriş}

İnsanın davranışlarını yönlendiren en önemli etkenin gereksinimleri olduğunu savunarak güdülenme olgusunu açıklamaya çalışan Maslow'un, ortaya koyduğu ihtiyaçlar hiyerarşisinde güvenlik intiyacı insan yaşamında karşılanması gereken birincil intiyaçlar arasında yer almaktadır (Sabuncuoğlu ve Tüz, 1995, s. 101). İş yaşamı, insan yaşamının önemli bir parçasını oluşturduğu gibi yaşamın diğer alanlarını da etkilemektedir. Bu nedenle iş yaşamında Maslow'un güvenlik ihtiyacına karşılık gelen, "Güvence ilkesi" nin uygulanması, gerek iş alanında gerekse yaşamının diğer alanlarında çalışanlar açısından kritik bir öneme sahiptir. Küreselleşmenin etkisiyle değişen sosyo-ekonomik koşullara ayak uydurabilmek amacıyla yapısal değişimler geçiren örgütlerde, çalışanların iş güvencesinin ve güvencenin araçlarından biri olan sendikalaşma oranlarının gittikçe azaldığı görülmektedir (Kayıkçı, 2013). Bu durum çalışanların işsizliğine veya işsizlik tehlikesinin artmasına, statü ve ücret kayıplarına ve artan performans baskısına maruz kalmalarına neden olmuştur. Tüm bu gelişmelerin sonucu olarak iş güvencesinin çalışanlar için hayati bir konu haline geldiği söylenebilir.

Eğitim yönetimi açısından örgütün amaçları ve üretim boyutu kadar insan (çalışanların gereksinimleri) boyutu da önemlidir. Bu nedenle gerek kamu yönetiminde ve gerekse eğitim yönetiminde insan kaynakları yönetiminin önemli ilkelerinden biri olan güvence ilkesi (Can, 2001; Yüksel, 1997) uygulama alanında yasal zeminde de yerini almaktadır. Alanyazın incelendiğinde genel olarak iki tür güvenceden bahsedilmektedir. Bunlar iş güvencesi ve makam güvencesi olarak belirtilebilir. İ̧̧ güvencesi kişinin haklı bir neden olmaksızın işten çıkarılmamasını ifade ederken; makam güvencesi ise kişinin yükseldiği makamdaki görevini koruyabilmesini ifade etmektedir (Bilgin, 2011; Tortop, Aykaç, Yayman ve Özer, 2007). İş güvensizliği ise, tehdit altındaki bir işin arzu edilen bir devamlılığı sağlamak için algılanan güçsüzlük (Greenhalgh ve Rosenblatt, 1984), mevcut işin sürekliliğine engel olacak her türlü yasal veya yasal olmayan örgütsel değişimler sonucunda ortaya çıkan, iş görende, belirsizlik düşüncesine dayalı olarak işini kaybetme kaygısı doğuran durumlar (Karacaoğlu, 2015, s. 13) olarak tanımlanmıştır. Memuriyet kavramı bürokraside çalışanların iş güvencesini içinde barındıran temel kavramlardan biridir. Weber'e göre memuriyet bir meslektir, memurun daima sosyal bir statüsü vardır, hizmetin karşılığı olarak ücret ve çalışanların geleceği için güvenlik sağlanır (Bursalıoğlu, 2014, s. 20). Weber'in ideal tip bürokrasisinde açık ve net bir işbölümü, kurallar ve yönetmelikler sistemi, tarafsız bir tutum, örgütte çalışma süresi boyunca çalışma garantisi içinde bulunmaktadır (Aydın, 2014, s. 70). Memurlar, devlet güvencesi kapsamına alındığından belirli bir çalışma yılı veya yaşta emekli olana kadar çalışır. Daha sonra emekli ikramiye ve aylığı alarak ömür boyu sağlık güvencesi gibi haklara sahip olurlar (Öztekin, 1993).

Memur güvencesi, öteden beri kamu yönetiminde tartışılagelen önemli konular arasında yer almaktadır. Bir kısım çalışan, devlet memurluğuna çalışanlara iş güvencesi sağlaması açısından olumlu bakarken, bir kısım yönetici ise, bunun çalışanları verimsizliğe sürüklediğini düşünerek devlet memurluğu yoluyla istihdama karşı olumsuz bir düşünce taşımaktadır. Bu durumda örgütte bir yanda insan ve ilişki boyutu, diğer yanda ise örgüt ve üretim boyutu ön plana çıkmaktadır. Bu iki boyut birbirine ters gibi görünse de çağdaş eğitim yönetimi yaklaşımlarında kalite için her iki boyut aynı derecede önemli ve birbirini olumlu etkileyen konumdadır.

Çalışanların iş güvencesi, iş doyumu ve morali örgütün insan ve ilişki boyutunu önemli derecede etkileyen kavramlar arasında yer almaktadır. İs güvencesi, bireyin haklı nedenler olmadan işten atılamaması, iş doyumu, bir iş görenin örgütteki iş yaşamını değerlendirmesi sonucunda ulaştığı haz duygusu ya da ulaştığı olumlu duygusal durum (Demirtaş ve Güneş, 2002, s. 83), moral ise, bireyin amaçları ile içinde bulunduğu durum arasındaki farka ilişkin algılarının oluşturduğu zihinsel bir durum ya da tutum olarak tanımlanmaktadır (Demirtaş ve Güneş, 2002, s. 106). Makam güvencesine dayalı olarak çalışan kariyer sisteminde çalışanların göstermiş oldukları performansa göre örgüt hiyerarşisindeki konumlarının yükselmesi onların 
güdülenmesinin artmasına neden olur (Tunçer, 2013, s. 87). Bazı bireyler işe karşı negatif davranışlar sergilerken bazıları da iş güvencesizliğine karşı tedbir ve tepki olarak daha fazla performans sergilemekle birlikte bunların örgütlerine bağlılıklarının ise yüksek derecede olmadığı görülmektedir (Dede, 2017, s. 31).

Türkiye'de kamu yönetimi alanında "güvence" ilkesini düzenleyen çeşitli yasal dayanaklar bulunmaktadır. 657 sayılı Devlet Memurları Kanunu'nun (DMK) güvenlik başlıklı 18'inci maddesinde; "Kanunlarda yazılı haller dışında devlet memurunun memurluğuna son verilmez, aylık ve başka hakları elinden alınamaz" hükmüne yer verilerek hangi hallerde memurluğun sona erdirileceği açıkça belirtilmiştir (DMK, 1965). Ancak son yıllarda yapılan yasal düzenlemeler sonucunda iş güvencesi, Türkiye'de yoğun tartışma ve çalışmaların odağında yer almıştır. İşten çıkarma prosedürlerini düzenleyen ve zorlaştıran yasal düzenlemeler, özel sektör firmalarının insan kaynakları politika ve süreçlerinde yeniden yapılanmayı da zorunlu kılmıştır (Dığın, 2008, s. 1). Güvence ilkesi ile insan kaynakları yönetiminin diğer önemli ilkelerinden birisi olan yeterlik (liyakat) ilkesi arasında önemli bir ilişki bulunmaktadır. Özellikle makam güvencesi dikkate alındığında Türkiye'de olduğu gibi okul yöneticilerinin 4 yıllık (geçici) bir süre için görev yaptığı durumlarda atama kıstasları somut, bilimsel ve nesnel değilse (Kayıkçı, Özdemir ve Özyıldırım, 2015, s. 471) yöneticilerin makam güvencesinden bahsetmek mümkün değildir. Çünkü yeterliğe dayalı olmayan yönetici görevlendirmeleri aynı zamanda güvence ilkesini de zedeleyebilir.

Türkiye'de yasal olarak liyakat ilkesi benimsenmiştir. Başta anayasa olmak üzere 657 sayılı devlet memurları kanununun temel ilkeleri arasında bulunan "Liyakat" şu şekilde tanımlanmışıı; "Devlet kamu hizmetleri görevlerine girmeyi, sınıflar içinde ilerleme ve yükselmeyi, görevin sona erdirilmesini liyakat sistemine dayandırmak ve bu sistemin eşit imkânlarla uygulanmasında Devlet memurlarını güvenliğe sahip kılmaktır." Buna göre, görevi yerine getirecek olan kişilerin de daimi statüde ve bir kariyere dayalı olarak çalıştırılması gerektiği belirtilmektedir. Buda kamu hizmetlerine girişte ve yükseltmelerde liyakat esaslarının uygulanmasını gerekli kılmaktadır. Devlet memurları kanununda memurun görev yeri değiştirilebilir ancak özlük haklarının korunmak zorunda olduğu belirtilmektedir. Memurun görevden atılması ancak memuriyetten çıkarılmayı gerektiren disiplin suçu işlemesi ya da 6 aydan fazla hapis cezası ile mahkûmiyetine karar verilmesi durumlarında mümkün olduğu belirtilmektedir.

Kapitalist dünyada memurların sahip oldukları güvence dolayısıyla sosyal devlete alternatif olarak önerilen sistem, bireysel inisiyatifi daha ön plana çıkaran liberal devlet modelidir. Buna göre liberal devlette hem devletin sırtında sosyal hakların ve memuriyetin yükü olmayacak, hem de serbest girişimcilik desteklenecektir. Liberal devlet savunucuları, sosyal devlet modellerinde ortaya çıkan yozlaşmanın ve kayırmacılığın liberal devlette azalacağını da öne sürmektedir (Kara, 2009, s. 369). Ancak 2020 yılında dünyada baş gösteren Coronavirüs salgını sosyal devlet ve güvence ilkesinin çalışma hayatında ne kadar büyük bir öneme sahip olduğunu göstermiştir.

Türkiye'de memurluğun sadece bir iş güvencesi olarak algılanması, objektif bir performans değerlendirme ve buna dayalı ödül ve ceza sisteminin iyi işlememesi ve bunun sonucunda kamu ve eğitim yönetimindeki verimsizlik eleştirilere neden olmaktadır. Hâlbuki güvence ilkesinin yanında ödülün kullanılması, eğitim çalışanlarının çalışmaya güdülenmesi (Sarpkaya, 2014, s. 225) ve örgütü yaşatmak için gerekli olan performansın (Aydın, 2013) artırılmasında önemli bir yer tutar. Güvenceden mahrum bir ortamda çalışan öğretmenin işten memnuniyetinin azalması beklenir. Türk eğitim sisteminde öğretmenlerin çalışma koşullarından memnun olmamaları onların mesleklerini gerektiği şekilde icra edememelerine yol açabilmektedir (Dede, 2017, s. 4). Meslek örgütlerinin olmaması (Toprakçı, 2009) ve genel olarak eğitimde (Toprakçı, Çakırer, Bilbay, Bagcivan ve Bayraktutan 2010) özel olarak öğretmenlikte (Toprakci. Bozpolat ve Buldur 2010) meslek ahlakı belirsizliği onların çalışma koşullarını etkilemektedir. Meslek örgütünün olmayışı (Sendika değil, Baro örneğin) gerek özel okul sahiplerini gerekse hükümetleri öğretmenlik işinin meslekleşmesinde tek belirleyici yapabilmektedir. Etkin bir performans değerlendirme, ödüllendirme, cezalandırma ve kariyer sisteminden mahrum bir güvence sistemi, okullarda insan kaynağının zaman içinde değerini kaybetmesine, verimsizleşmesine ve çalışmaya 
ilişkin motivasyonunun düşmesine neden olabilir. Bununla beraber bireysel ve mesleksel gelişimlerini destekleyici örgütsel ortamlarda öğretmenlerin artan bir biçimde etkililik gösterdiğini ortaya koyan çeşitli araştırmalar vardır (Aydın, 2013, s. 39). Günümüzde performans değerlendirme sistemleri aracılığı ile personelin örgüte olan katkılarının artırılması, zayıf ve güçlü yönlerinin ortaya çıkarılması, eğitim gereksinimlerinin tespiti ve kariyer planlama amaçlanmıştır (Bakan ve Kelleroğlu, 2003, s. 124). Insan kaynakları yönetiminin en önemli görevlerinden biri çalışanların eksikliklerini tespit etmek, onları geliştirme programlarına tabi tutarak, diğer iş görenlerle aynı duruma getirmeye çalışmaktır (Mercin, 2005, s. 142). Performans değerlendirmesinin sağlıklı bir şekilde yapılmamış olması, performansa dayalı ücret sistemini olumsuz yönde etkileyeceği gibi, personel ile kurum arasındaki ilişkilerin bozulmasına da neden olabilir. Bu durum özellikle ayrımcılık yapıldığı fikrinin oluşmasına, güvensizlik ortamının doğmasına, saygınlığın azalmasına ve yönetimin zayıflamasına neden olabilir (Eren, 2006, s. 150). Yeni kamu yönetimi anlayışında personel yönetimi ilkeleri eşitlik ve tarafsızlık, kariyer, yeterlilik, başarı değerlendirmesi ve hesap verilebilirlik olarak yeniden sıralanmıştır. Gerekli eğitim, bilgi, yeterlik, tecrübe ve yetişme şartlarına uygun olarak yükselme ve ilerleme imkânından söz edilmiş, liyakat ilkesi, performans standartlarına dayandırılmıştır. Başarı değerlendirmesine geniş bir yer verilmiş, performans ödemesinden söz edilmiştir (Eroğlu, 2010, s. 229).

Bu çalışmanın amacl, Türk eğitim sisteminde uygulanan güvence ilkesinin öğretmen ve eğitim kurumları üzerindeki etkisini ortaya koymak ve daha etkili ve verimli bir işleyiş için öneriler sunmaktır. Bu araştırma, insan kaynakları yönetiminin önemli ilkelerinden biri olan Güvence ilkesine ilişkin Türk milli eğitim sistemindeki uygulamaları ortaya koyması, güvence ilkesinin örgüt ve birey boyutu üzerindeki etkilerini saptaması ve daha etkili bir işleyiş için uygulayıcılara öneriler sunması açısından önemlidir. Bu amaçla öğretmenlerin, devlet memurlarına uygulanan mesleki güvenceye, uygulanan mesleki güvencenin çalışanlara, çalışanların performanslarına ve örgüte etkisi hakkındaki görüş ve önerileri belirlenmeye çalışılmıştır. Bu çerçevede aşağıda verilen sorulara yanıt aranmıştır:

1- Öğretmenlerin "Mesleki Güvence Illkesi" kavramına ilişkin algıları nelerdir?

2- Öğretmenlerin mesleki güvence ilkesinin okullardaki uygulamalarında gördükleri olumlu yönler nelerdir?

3- Öğretmenlerin mesleki güvence ilkesinin okullardaki uygulamalarında gördükleri olumsuz yönler nelerdir?

4- Öğretmenlerin eğitim sistemindeki mesleki güvence uygulamaları ile okul çalışanlarının performansı arasındaki ilişki hakkındaki görüşleri nelerdir?

5- Öğretmenlerin Türk eğitim sistemindeki mesleki güvence uygulamalarına ilişkin beklentileri nelerdir?

\section{YÖNTEM}

Araştırmanın yöntemi nitel araştırma yöntemidir. Nitel araştırma, bireyler ve gruplar arasındaki sosyal ve bireysel problemlerin derinlemesine incelenmesidir. Araştırma, nitel araştırma yönteminin fenomenoloji desenine uygun olarak gerçekleştirilmiştir. Bu araştırmada öğretmenlerin mesleki güvenceye ilişkin deneyimlerini ve karşılaştıkları olgu ve olayları nasıl anlamlandırdıklarını, mesleki güvenceye ilişkin düşünce yapılarını ve özünü belirlemek amaçlandığı için Fenomenoloji deseni seçilmiştir. Fenomenoloji deseninin temeli, bir kişi veya bir grup için yaşanılan deneyimin anlamı, yapısı ve özünü araştırmaktadır (Patton, 2001). Fenomenoloji deseni "kişilerin deneyimleri, hayatı anlamlandırma biçimleri, olanlar ile onları anlama şekilleri arasındaki ilişkiyi, bir olayı yaşama biçimlerini, kişilerarası deneyimlerin ortak noktalarını" araştırırken kullanılmaktadır (Edmonds ve Kennedy, 2017, s. 170). Bu yönüyle olgu bilim uygun bir araştırma zemini oluşturmaktadır. Veri toplama yöntemi olarak görüşme yöntemi kullanılmıştır. Görüşme, nitel araştırmada en sık kullanılan veri toplama aracıdır. Veri toplamak amacıyla yarı yapılandırılmış görüşme formu kullanılmıştır. Görüşme formu, ilgili alanyazın incelenerek oluşturulmuş, uzman görüşüne sunulmuştur. Görüşme formunun birinci bölümünde 
kişisel bilgilere ilişkin sorulara, ikinci bölümünde ise Türk milli eğitim sisteminde uygulanan güvence ilkesinin öğretmen ve örgüt üzerindeki etkisi ile ilgili görüşlerini belirlemek üzere ana ve sonda sorulara yer verilmiştir (Creswell, 2014; Yıldırım ve Şimşek, 2013).

Araştırmanın Çalışma Gurubu, Antalya ilinde, merkez ilçelerde ortaöğretim okullarında görev yapan öğretmenler arasından seçilmiştir. Çalışma gurubunun belirlenmesinde maksimum çeşitlilik örneklemesi kullanılmıştır. Bunun için mümkün olduğu kadar farklı branş ve kıdemden öğretmenler seçilmiş ve üç ayrı okuldan katılımcı sağlanmıştır. Öğretmenlerin seçiminde "gönüllülük" ölçüsü esas alınarak, mesleki deneyiminin fazla olmasına özen gösterilmeye çalışılmıştır. Bu çerçevede görüşmeler ortaöğretim kademesinde çalışan 14 öğretmen ile yapılmıştır. Görüşmeler yüz yüze gerçekleştirilmiştir. Görüşmeler ses kaydı ile kayıt altına alınmış ve not tutma yöntemi ile desteklenmiştir. Analiz aşamalarında NVIVO 10 nitel araştırma paket programı kullanılarak içerik analizi ve betimsel analiz yapılmıştır (Creswell, 2014; Yıldırım ve Şimşek, 2013).

Içerik analizinde temel amaç, toplanan verileri açıklayabilecek kavramlara ve ilişkilere ulaşmaktır. Betimsel analizde özetlenen ve yorumlanan veriler, içerik analizinde daha derin bir işleme tabi tutulur ve betimsel bir yaklaşımla fark edilmeyen kavram ve temalar bu analiz sonucu keşfedilir (Yıldııım ve Şimşek, 2013, s. 259). Verilerin çözümlenmesinde katılımcılar kodlanmıştır. Katılımcıların kod numaraları (Ö) kısaltması ile Ö1, Ö2, Ö3,..., Ö14 şeklinde belirtilmiştir. Tablolarda özet olarak sunulan katııımc görüşleri tablo altlarında sunulan doğrudan alıntılarla desteklenerek açıklanmıştır.

Geçerlik ve Güvenirlik: Nitel araştırmalarda geçerlik ve güvenirlik kavramları yerine inandırıcılık, aktarılabilirlik, tutarııık ve teyit edilebilirlik kavramları kullanılmaktadır (Mills, 2003). Araştırmacı, araştırmanın tüm aşamalarında mümkün olduğunca objektif olmaya dikkat etmiştir. Kodlamalar sürecinde araştırmacı kendisi dışında uzman görüşlerine de başvurarak kodlamaların doğru bir şekilde oluşturulması sağlanmıştır. Kodlama ve kategorileştirme ayrıntılı bir şekilde ifade edilerek geçerlik artırımaya çalışımıştır. İkinci aşamada nitel verilerin güvenirliğinin analizi yapılmıştır. Nitel araştırmanın iç güvenirliğini (tutarlıı̆ını) artırmak için tutarlıık incelemesi yönteminden yararlanılmıştır. Araştırmada verilerin analizinde güvenirliğin ve tutarlığın sağlanması açısından araştırmanın araştırmacılar ayrı ayrı kodlamalarda bulunmuş ve iki ayrı araştırmacının kodlamaları arasındaki uyum karşılaştırılmıştır. Buna göre iki araştırmacının kodlamaları arasındaki uyuma ilişkin KohenKappa tutarlılık katsayısının 0.92 düzeyinde anlamlı olarak hesaplandığı görülmüştür. KohenKappa tutarlıık katsayısının 0.80 ile 1.00 arasında olması, mükemmel bir uyum olduğu şeklinde yorumlanmaktadır (Landis ve Koch, 1977, s. 165). Ayrıca araştırmada elde edilen bulgular katılımcılarla paylaşılış ve bu bulguların katılımcıların deneyimleriyle uyumlu olduğu katılımcılar tarafından belirtilerek katıımcı teyidi alınmıştır.

\section{BULGULAR}

Bu bölümde Türk milli eğitim sisteminde uygulanan güvence ilkesinin öğretmen ve örgüt üzerindeki etkisini ortaya koymak amacıyla hazırlanan alt problemlere ilişkin araştırma bulgularına yer verilmiştir.

\section{1- Öğretmenlerin Milli Eğitim Bakanlığı Tarafından Uygulanan “Mesleki Güvence ilkesi" ne İlişkin Algıları}

Öğretmenlerin Milli Eğitim Bakanlığı tarafından uygulanan "mesleki güvence IIlkesi" ne ilişkin algılarını içeren bulgular tablo 1'de yer almaktadır.

Tablo1'de verilen öğretmenlerin mesleki güvence ile ilgili algıları incelendiğinde öğretmenlerin 7 ayrı görüş belirttikleri görülmektedir. Buna göre öğretmenler Milli Eğitim Bakanlığı tarafından uygulanan mesleki güvencesi ilkesinin; " Güvence, iş ahlakı ile birleşince iş kalitesi olduğunu (7), Hakların yasalarla korunması olduğunu (7), psikolojik rahatlık olduğunu (8), 
sosyal devlette sosyal güvenlik olduğunu (5), yaşam hakkı olduğunu (2), eksikliğinin eğitim kalitesini etkilemediğini(3) ve çalışanlarda informal etkilere karşı direnç sağladığını (10)" belirtmişlerdir.

Tablo 1. Öğretmenlerin “Mesleki güvence ilkesi” ne ilişkin algıları

\begin{tabular}{|c|c|c|c|c|c|c|c|c|c|c|c|c|c|c|c|c|}
\hline & & Ö1 & Ö2 & 0̈3 & Ö4 & Ö5 & Ö6 & ö7 & Ö8 & Ö9 & Ö10 & Ö11 & Ö12 & Ö13 & Ö14 & $f$ \\
\hline & Mesleki güvence; & & & & & & & & & & & & & & & \\
\hline 1 & $\begin{array}{l}\text { İş ahlakı ile } \\
\text { birleşince iş kalitesi } \\
\text { artar. }\end{array}$ & $\sqrt{ }$ & $\sqrt{ }$ & & $\sqrt{ }$ & & & $\sqrt{ }$ & $\sqrt{ }$ & & $\sqrt{ }$ & $\sqrt{ }$ & & & & 7 \\
\hline 2 & $\begin{array}{l}\text { Haklar yasalarla } \\
\text { korunması sağlanır. }\end{array}$ & & & & $\sqrt{ }$ & $\sqrt{ }$ & $\sqrt{ }$ & $\sqrt{ }$ & & $\sqrt{ }$ & & & $\sqrt{ }$ & & $\sqrt{ }$ & 7 \\
\hline 3 & $\begin{array}{l}\text { Psikolojik rahatlık } \\
\text { sağlar. }\end{array}$ & & $\sqrt{ }$ & $\sqrt{ }$ & $\sqrt{ }$ & & $\sqrt{ }$ & $\sqrt{ }$ & & & $\sqrt{ }$ & & & $\sqrt{ }$ & $\sqrt{ }$ & 8 \\
\hline 4 & $\begin{array}{l}\text { Sosyal devlette, } \\
\text { sosyal güvence } \\
\text { gücü sağlar. }\end{array}$ & & $\sqrt{ }$ & & & $\sqrt{ }$ & $\sqrt{ }$ & & $\sqrt{ }$ & & & $\sqrt{ }$ & & & & 5 \\
\hline 5 & $\begin{array}{l}\text { Yaşam hakkını } \\
\text { koruma altına alır. }\end{array}$ & & & & & & & & $\sqrt{ }$ & & & $\sqrt{ }$ & & & & 2 \\
\hline 6 & $\begin{array}{l}\text { Güvence tek başına } \\
\text { performansı } \\
\text { arttırmaya yeterli } \\
\text { değildir. }\end{array}$ & $\sqrt{ }$ & & & & & & & & & $\sqrt{ }$ & & & $\sqrt{ }$ & & 3 \\
\hline 7. & $\begin{array}{l}\text { Çalışanların informal } \\
\text { etkilere karşı } \\
\text { direncini güçlendirir }\end{array}$ & $\sqrt{ }$ & $\sqrt{ }$ & $\sqrt{ }$ & $\sqrt{ }$ & $\sqrt{ }$ & $\sqrt{ }$ & & & $\sqrt{ }$ & & & $\sqrt{ }$ & $\sqrt{ }$ & $\sqrt{ }$ & 10 \\
\hline
\end{tabular}

Güvence İlkesinin, iş ahlakı ile birleşince iş kalitesi oluştuğunu savunan bazı katılımcılar bu görüşlerini şu şekilde ifade etmişlerdir: ö10: “Öğretmenler odasında zil çalınca bir öğretmen derse gitmeyi geciktiriyor başka bir tanesi hemen zil çalar çalmaz derse gidiyor. Bu yetiştirilmeyle alakalı, güvenceyle alakalı değil bence, Mesleki güvenceyi alırsan, zil çalar çalmaz dersine gider ama bu sefer derste oturur. Nitelikli ders geçirmez. İş ahlakı ile ilgili bir şey.", Ö2: "Güvence var ya, öğretmen onu bildiği için işin gereklerini suiistimal edici davranışlar ortaya çıkıyor. Kurumda farklı kutuplar ortaya çıkıyor. Yani çalışan öğretmen ve işini olduğu kadar yapan öğretmen oluşuyor. Buda kutuplaşmaya sebep oluyor. Zamanla iş ilişkileri de dejenere oluyor.", şeklinde ifade kullanmıştır.

Hakların yasalarla korunması anlamına geldiğini öne süren bazı katılımcılar görüşlerini şu şekilde ifade etmişlerdir: Ö12: "Mesleki güvence bence hukuksal anlamda hakların yasalar ile korunmasıdır", Ö7: "Mesleki güvence siyasi erkin keyfine kalmadan mesaiyi rahat ve özgür bir şekilde yapabilmek." demişlerdir.

Güvence ilkesinin psikolojik rahatlık ifade ettiğini öne süren bazı katılımcılar şunları ifade etmişlerdir: ö13: "Mesleki güvence bence kişinin işini icra ederken kaygı duymadan çalışabilmesi, hem gelecek hem şimdiki zaman. Rahatlık buda hayata yansıyor. Psikolojik olarak daha rahat hissediyorsun.",ö14: "Insanın kendini psikolojik anlamda güvende hissetmesi tabiki olumlu. Yaptığın işin karşıı̆ı̆ı alacağını 1 ay önceden bilmen psikolojik açıdan olumlu yansıma yapar" şeklinde ifade kullanmıştır.

Bazı katılımcılar güvence ilkesini sosyal devlette sosyal güvence anlamına geldiğini şu şekilde açıklamıştır: Ö11: "Sosyal devlette insanlara güvence verilmesi zaten kaçınılmaz. Bizim hukukumuza göre bizim devletimiz sosyal bir devlet olduğu için sosyal güvencenin yanında tabiki mesleki güvence olması da gayet doğal", ö8: " Bir ülkede yaşayan her insanın güvencesi olmak zorunda. İster çalışsın ister çalışmasın her birey geleceğe kaygısız bakmak gibi bir insan hakkına sahip. Sağık açısından ekonomik açıdan güvence ile kaygım olmadan bakabileyim ki üretkenliğim 
ortaya çıkabilsin. Sağlık sorunlarım varsa ve devlet bana bakmıyorsa ve ekonomik gelirim bunu karşılamaya yetmiyorsa işimi ne kadar yapabilirim bu tartışııı" demişlerdir.

Güvence ilkesinin bir yaşam hakkı olduğunu belirten bir katılımcı bu görüşünü şu şekilde ifade etmiştir: 0̈11: "Güvence yaşam hakkıdır bence. Insanların yaşamını devam ettirebilmesi içinde her şeyden önce sağık, sonra gıda vb. gibi temel ihtiyaçlarını giderebilmesi gerekir. Pek çok toplumda ve bizde de işsizlik maaşı veriliyor. Bu insanlara en azından hayatını devam ettirebilme garantisi veriyor"

Sadece güvence ilkesinin uygulanmasının işin kalitesine katkı sağlamadığını öne süren bazı öğretmenler görüşlerini şu şekilde açıkladılar: ö1: “Öğretmenler arasında da bu düşünceye zaman zaman şahit oluyoruz. Dersime girip çıkayım, zamanında geleyim diyor öğretmen ama yapılan eğitimin kalitesinin yapılan eğitim-öğretime ve öğrenciye hiçbir katkısı yok. lç̧inde bulunduğumuz sistemde değerlendirme ancak bu şekilde oluyor."

Güvence ilkesinin çalışanların informal etkilere karşı direnç sağladığını belirten bir katııımcı bu konudaki görüşlerini şu şekilde ifade etmiştir: Ö14: "Kendini güvence altında hissetmeyen devlet memuru ister öğretmen olsun ister okul müdürü olsun başkalarının ve özellikle amirlerinin veya siyasilerin daha fazla etkilerinde kalırlar. Bazen bunların usulsüz taleplerine karşı da direnemeyebilirler bazen duyuyoruz stajyer öğretmenler stajyerliklerini kaldırana kadar kendilerini güvence içinde hissetmedikleri için bazen okul müdürlerinin görevleri olmayan okul ve idari işleri stajyerlere yaptırdıklarını duyuyoruz. Hâlbuki kendini yasal güvence altında gören bir ögretmen görevi olmayan işleri yapmaz ve buna karşı direnir." Ö2: "Geçici görevli oldukları için bazı okul müdürleri tekrar görevlendirilebilmeleri için bazen müdürlerinin taleplerini yasalardan öncelikli algılamaktadırlar, hâlbuki güvence içinde olan bir okul müdürü gücünü sadece yasalardan alacağı için uygun olmayan taleplere karşı daha dirençli olacaktır"

\section{2- Öğretmenlerin Mesleki Güvence ilkesinin Okullardaki Uygulamalarında Gördükleri Olumlu Yönlere iliş̧kin Görüşleri}

Öğretmenlerin mesleki güvence ilkesinin olumlu yönlerine ilişkin görüşleri Tablo 2'de verilmiştir.

Katılımcılar uygulanan güvence ilkesinin kurumsal açıdan ve bireysel açıdan olumlu yönleri olduğunu belirtmişlerdir. Kurumsal açıdan olumlu yönleri arasında, işin kalitesini, işe aidiyet duygusunu artırır (9) ve Örgütte psikolojik gerilimi ve sorunları azaltır (2), Performans artar (2) Güven hissi iş motivasyonunu artırıyor" şeklinde ifadeler yer alırken; Çalışanlar açısından olumlu yönleri arasında ise, çalışanlar kendilerini güvende hisseder (2), iş doyumu artar(2), ilişkiler samimileşir (2), Öğretmenlerin eğitimini pozitif etkiler (2), Mesleki güvence, güdüleme ile orantılı olmalı(2). Mesleki güvencenin olmaması psikolojik baskı yaratır ( 2) gibi görüşler yer almıştır.

Güvence ilkesinin Türk eğitim sistemindeki uygulamalarını çalışanlar açısından olumlu bulan bazı katılımcılar görüşlerini şu şekilde ifade etmişlerdir: ö12: "Olumlu yanı, çalışanın kendini güvende hissetmesidir. Mesleğin niteliğinin ve performansının artmasını sağlar. Çalışanda daha çok iş doyumu sağlar. Daha verimli çalışma ortamı oluşmasını sağlar. ö14:" Ertesi günün kaygısı ile yaşamak çok zor. Özel sektördeki insanlar evet çok fazla çaba sarf ediyor ama bunun yanında o stresi de çok fazla yaşıyorlardır. Her sene sözleşme yenilenecek mi yenilenmeyecek mi kaygısı zor."",ö1: "Eğer mesleki güvenceyi hissediyorsanız bu kesinlikle pozitif etkiliyor. Psikolojik olarak bizi etkiliyor. Böylece kuruma bağlığın artıyor. Bence resmi ilişkiler, samimi ilişkiler ile desteklenirse kurumun başarısı, performansı artıyor. Bu iyi kötü günde birliktelik hissi yaratıyor. Kaygın azalıyor.", 
Tablo 2. Öğretmenlerin mesleki güvence ilkesinin okullardaki uygulamalarında gördükleri olumlu yönlere ilişkin görüşleri

\begin{tabular}{|c|c|c|c|c|c|c|c|c|c|c|c|c|c|c|c|c|}
\hline \multirow{6}{*}{ 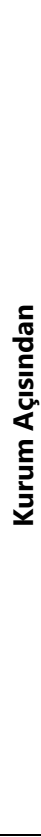 } & Görüşler; & Ö1 & Ö2 & Ö3 & Ö4 & Ö5 & Ö6 & Ö7 & Ö8 & Ö9 & Ö10 & Ö11 & Ö12 & Ö13 & Ö14 & $f$ \\
\hline & $\begin{array}{l}\text { İşin kalitesini, işe } \\
\text { aidiyet } \\
\text { duygusunu } \\
\text { artırır. }\end{array}$ & $\sqrt{ }$ & $\sqrt{ }$ & $\sqrt{ }$ & & & & & $\sqrt{ }$ & $\sqrt{ }$ & $\sqrt{ }$ & $\sqrt{ }$ & $\sqrt{ }$ & $\sqrt{ }$ & & 9 \\
\hline & $\begin{array}{l}\text { Örgütte } \\
\text { psikolojik } \\
\text { gerilimi ve } \\
\text { sorunları azaltır. }\end{array}$ & & & & & & & & & & & $\sqrt{ }$ & & $\sqrt{ }$ & & 2 \\
\hline & $\begin{array}{l}\text { Bireyin kendini } \\
\text { güvende } \\
\text { hissetmesiyle } \\
\text { veriminin } \\
\text { artmasına yol } \\
\text { açar. }\end{array}$ & & & & & & & & & & $\sqrt{ }$ & $\sqrt{ }$ & $\sqrt{ }$ & $\sqrt{ }$ & $\sqrt{ }$ & 5 \\
\hline & $\begin{array}{l}\text { Güven hissiyle iş } \\
\text { motivasyonunda } \\
\text { artış olur. }\end{array}$ & & & & & & & $\sqrt{ }$ & & & & & $\sqrt{ }$ & & & 2 \\
\hline & $\begin{array}{l}\text { Güvence algısı } \\
\text { kurumda } \\
\text { çatışmayı } \\
\text { azaltıyor. }\end{array}$ & & & & & $\sqrt{ }$ & & & & & & & & $\sqrt{ }$ & & 2 \\
\hline \multirow{6}{*}{ 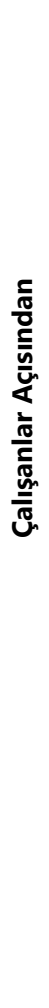 } & $\begin{array}{l}\text { Çalışanların } \\
\text { kendilerini } \\
\text { güvende } \\
\text { hissetmelerine } \\
\text { yardım eder. }\end{array}$ & & & & & & & & & & $\sqrt{ }$ & $\sqrt{ }$ & $\sqrt{ }$ & $\sqrt{ }$ & $\sqrt{ }$ & 5 \\
\hline & $\begin{array}{l}\text { İş doyumunun } \\
\text { artmasına } \\
\text { yardımcı olur. }\end{array}$ & & & & & & & & & & & $\sqrt{ }$ & & $\sqrt{ }$ & & 2 \\
\hline & $\begin{array}{l}\text { İlişkilerde } \\
\text { samimiyet artışı } \\
\text { sağlar. }\end{array}$ & $\sqrt{ }$ & & & & & & $\sqrt{ }$ & & & & & & & & 2 \\
\hline & $\begin{array}{l}\text { Öğretmenlerin } \\
\text { gelişmesine } \\
\text { olumlu katkı } \\
\text { sağlar. }\end{array}$ & & & $\sqrt{ }$ & & & & & & & & $\sqrt{ }$ & & & & 2 \\
\hline & $\begin{array}{l}\text { Mesleki } \\
\text { güvence ve } \\
\text { güdüleme eş } \\
\text { oranda } \\
\text { kullanıldığında } \\
\text { olumlu etki } \\
\text { yaratır. }\end{array}$ & & & $\sqrt{ }$ & & & & & & $\sqrt{ }$ & & & & & & 2 \\
\hline & $\begin{array}{l}\text { Güvence } \\
\text { psikolojik } \\
\text { sorunları azaltır, } \\
\text { güvencesizlik } \\
\text { baskı yaratır. }\end{array}$ & $\sqrt{ }$ & & & & $\sqrt{ }$ & $\sqrt{ }$ & & & & & $\sqrt{ }$ & & $\sqrt{ }$ & & 5 \\
\hline
\end{tabular}

Güvence ilkesinin Türk eğitim sistemindeki uygulamalarını Kurumsal açıdan olumlu bulan bazı katılımcılar görüşlerini şu şekilde ifade etmişlerdir: Ö12: "Psikolojik etkisinin olumlu yanı kendini güvende hissetme olabilir. Eğer kendimi güvende hissedersem işim daha iyi olur daha motive olurum." ö1: "mesleki güvence ile öğretmenler kaygıdan uzaklaşmaktadır, kaygı ögretmenlerin özgürlüklerini ve verimliliklerini düşürür. Kaygıyla yaşayan öğretmen kurallara uymak ve istenilen çerçevede öğretmen olabilmek için yaratıcılı̆ından ve sınıf içi performansından ödün vermektedir." 


\section{3- Öğretmenlerin Mesleki Güvence illkesinin Okullardaki Uygulamalarında Gördükleri Olumsuz Yönlere iliş̧kin Görüşleri}

Öğretmenlerin mesleki güvence ilkesinin uygulamada görülen olumsuz yönlerine ilişkin görüşleri tablo 3 'te verilmiştir.

Tablo 3. Öğretmenlerin mesleki güvence ilkesinin okullardaki uygulamalarında görülen olumsuz yönlerine ilişkin görüşleri

\begin{tabular}{|c|c|c|c|c|c|c|c|c|c|c|c|c|c|c|c|c|}
\hline \multirow{6}{*}{ 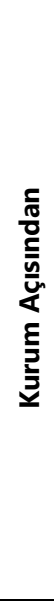 } & Görüşler; & Ö1 & Ö2 & Ö3 & Ö4 & Ö5 & Ö6 & Ö7 & Ö8 & Ö9 & Ö10 & Ö11 & Ö12 & Ö13 & Ö14 & $f$ \\
\hline & $\begin{array}{l}\text { Kişide kaygısızlığa yol } \\
\text { açıyor. }\end{array}$ & & $\checkmark$ & $\checkmark$ & $\checkmark$ & $\checkmark$ & & $\sqrt{ }$ & & $\checkmark$ & & $\checkmark$ & & & & 7 \\
\hline & $\begin{array}{l}\text { Kurumda } \\
\text { monotonluğu } \\
\text { artırıyor. } \\
\end{array}$ & & $\checkmark$ & $\checkmark$ & $\checkmark$ & $\sqrt{ }$ & & & & & & & & & & 4 \\
\hline & $\begin{array}{l}\text { Örgütte işin niteliğini } \\
\text { düşürüyor. }\end{array}$ & & $\checkmark$ & & & & & & & & $\checkmark$ & & & & & 2 \\
\hline & $\begin{array}{l}\text { Mesleki güvencenin, } \\
\text { rahatlığı işin kalitesini } \\
\text { düşürüyor. } \\
\end{array}$ & & $\checkmark$ & $\checkmark$ & $\checkmark$ & $\checkmark$ & & & & $\checkmark$ & & $\checkmark$ & & & & 6 \\
\hline & $\begin{array}{l}\text { Mesleki güvence } \\
\text { güdüleme ile orantılı } \\
\text { değil. }\end{array}$ & & & $\checkmark$ & & & & & & & $\checkmark$ & & & & & 2 \\
\hline \multirow{6}{*}{ 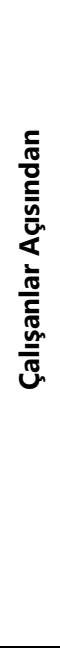 } & $\begin{array}{l}\text { Çalışanda adalet } \\
\text { duygusunu zedeliyor. }\end{array}$ & & & $\checkmark$ & $\checkmark$ & & & & & $\checkmark$ & & & & & $\checkmark$ & 3 \\
\hline & $\begin{array}{l}\text { Kişide tükenmişlik } \\
\text { hissini artırıyor. }\end{array}$ & & $\checkmark$ & $\checkmark$ & $\checkmark$ & $\checkmark$ & & & & & & & & & & 4 \\
\hline & $\begin{array}{l}\text { M. güvence olumsuz } \\
\text { ilişki ve mutsuzluğa } \\
\text { neden oluyor }\end{array}$ & & & & & & $\checkmark$ & & & & & & & $\checkmark$ & & 2 \\
\hline & $\begin{array}{l}\text { Mesleki güvence } \\
\text { meslek ahlakını } \\
\text { olumsuz etkiliyor. }\end{array}$ & & $\checkmark$ & & & & & & & & $\sqrt{ }$ & & & & & 2 \\
\hline & $\begin{array}{l}\text { Mesleki güvence } \\
\text { güdüleme ile } \\
\text { orantısızdır. } \\
\end{array}$ & & & $\checkmark$ & & & & & & & & & $\sqrt{ }$ & & & 2 \\
\hline & $\begin{array}{l}\text { Güvencesizlik } \\
\text { psikolojik baskı } \\
\text { yaratır. }\end{array}$ & $\sqrt{ }$ & & & & $\sqrt{ }$ & & & & & & & & & & 2 \\
\hline
\end{tabular}

Katılımcılar Türk eğitim sisteminde uygulanan güvence ilkesinin kurum ve çalışanlar açısından bazı olumsuz yönleri olduğunu belirtmişlerdir. Katılımcıların güvence ilkesinin uygulanmasında kurumsal açıdan olumsuz olarak gördükleri yönler arasında kişide kaygısızlığa yol açıyor (7), örgüte işin niteliğini düşürüyor (4) ve kurumda monotonluğu artırıyor (2), mesleki güvence ile psikolojik rahatlama işin kalitesini düşürüyor (6) şeklinde ifadeler yer alırken; çalışanlar açısından gördükleri olumsuz yönleri arasında ise, çalışanda adalet duygusunu negatif etkiliyor (3), kişide tükenmişlik hissini artırıyor(4), mesleki güvence kurumda negatif ilişkilere, mutsuzluğa neden oluyor (2), mesleki güvence güdüleme ile orantılı olmalı(2) gibi görüşler yer almıştır.

Türk eğitim sisteminde güvence ilkesinin uygulanmasının kurum açısından bazı olumsuz sonuçlar doğurduğunu savunan bazı katılımcılar bu konudaki görüşlerini şu şekilde ifade edilmiştir: Ö2: "Meslek ahlakı kavramının güvence sebebiyle dejenere olduğunu düşünüyorum. Mesleki güvenceyi kötüye kullanıyor. Kişisel çıkarların ön plana alındığı çalışanlar haline dönüştük." Ö11: "Ama diğer tarafta nasılsa ben maaşımı alıyorum iş bir şekilde yürüyor nasıl yürürse yürüsün deniyor. Bunun da olumsuz psikolojik etkisini görüyoruz. Bu olumsuz etki 
sebebiyle ortaya konulabilecek başarı da gösterilemiyor. Ya da sağlanan kaynaklar yeterli kullanılamıyor. Bizim toplumumuzda belirli güvence varsa rahat hareket edilir.",Ö3:"Mesleki güvence hayatsal kaygıyı azaltıyor ama sistem içinde güvence sebebiyle performans düşüşü oluyor. Yıldan yıla tembelleşiyoruz. Mesleki güvencenin sağladığı haklara güvenip insanlar çalışmıyor. İşin niteliği düşüyor. Grup çalışmasını kesinlikle olumsuz etkiliyor. Yapsam da yapmasam da olur ruhu oluşuyor. Bu düşüncenin etkisiyle hevesli olmak etkili olmuyor.", Ö4: "Çevremde de bir şey yapılmaya kalkışlınca" ne gerek var "tavrı ile karşılaşıyorum. Yani devlette çok çalışmayacaksın, başarılı olmaya kalmayacaksın sanki çünkü sürekli sistemsel engeller ile karşılaşıyoruz.".

Türk eğitim sisteminde güvence ilkesinin uygulanmasının çalışanlar açısından bazı olumsuz sonuçlar doğurduğunu savunan bazı katılımcılar bu konudaki görüşlerini şu şekilde ifade edilmiştir: Ö2: "Aslında mesleki güvence ile kaygı hissiyatımız yok denecek kadar azalıyor ancak zaman içinde özgüvenimizi yitiriyoruz. Dünya değişiyor, insanlar ve ihtiyaçları da değişiyor. Böylece eğitim sisteminden beklenenlerde değişiyor. Ancak benzer olanı tekrar etmek yenileşmekten kolay olduğu için güvence nasılsa var diye kolayı tercih ediyoruz. Çünkü zor olanı yani değişimi tercih etmemiz için zorlayıcı bir sebep yok. Ama buda zamanla monotonluk, mutsuzluk getiriyor. Sonuçta meslekten haz alamayan, tükenmişlik yaşayan bireyler oluyoruz. ö5: "Psikolojik açıdan mesleki tatmin yaşamıyoruz. Yani üretmiyoruz ve monoton bir hayata dönüşüyor bu durum. Böyle mutluluk olmaz. Keşke ürettiğimizi hissetsek ve çalıştığımızda bir karşılı̆ı olacağını görebilsek."

\section{4- Öğretmenlerin Eğitim Sistemindeki Mesleki Güvence Uygulamaları ile Okul Çalışanlarının Performansı Arasındaki iliş̧ki Hakkındaki Görüşleri}

Öğretmenlerin eğitim sistemindeki mesleki güvence uygulamaları ile okul çalışanlarının performansı arasındaki ilişki hakkındaki görüşleri Tablo. 4'te sunulmuştur.

Öğretmenlerin Türk eğitim sistemindeki mesleki güvence uygulamalarının öğretmenlerin performansına etkisi hakkındaki görüşleri ile ilgili olarak, bazı katılımcılar: "Performans değerlendirmesi olduğunu düşünmüyorum (11), Uzmanlarla objektif bir değerlendirme yapılmıyor (11), Mesleki güvence performansı düşürüyor (4), Mesleki güvence performansı pozitif etkiler (7), Performans mesleki güvence ile değil iş ahlakı ile ilgilidir (7), Mesleki güvence güdüleyici bir performans değerlendirme ile anlamlıdır (11)." şeklinde görüş bildirmişlerdir.

Katılımcı bazı öğretmenler performans değerlendirmesi yapılmadığını ya da uygun bir şekilde yapılmadığını şu şekilde ifade etmişlerdir; 0̈10: "Performans değerlendirmesi diye bir şey yok bence. Siyaset etkisinde kalıyor sitem maalesef, durum böyle olunca mesleki güvence çalışanın siyasilerin etkisiyle savrulmasını önlüyor.", Ö3: "Bence öğretmenleri değerlendiren bir performans değerlendirmesi yok. Yapılanda adil değil. Yapıldığı varsayılıyor. Iyi bir öğretmensin ya da kötüsün kriteri yok. Yani bence performans değince yapılan çalışmaya, işlere bakılır ve bunun karşılında ücret, kariyer basamakları gibi takdir kriterleri yaratılı. Çalışan takdir edilir yani. Ama ben çalışanların takdir edildiğini göremiyorum, dolayısıyla çalışanın takdir edilmediği bir ortamda iş güvencesi zarar görmesini engellemiş oluyor.",ö7: "Liyakatten çok güç sahiplerine sahte bir sadakate bağlı bir değerlendirme sistemi var sanki. Buna uygun değilsen devlet memurluğu şemsiyesi seni koruyabiliyor, aksi durumda her an işten atılabilirim diye sürekli stres altında kalırsın. Çünkü maalesef eğitimde performans değerlendirmesi yok bence."

Bazı öğretmenler mesleki güvencenin performans üzerinde olumlu etkisi olduğunu savunurken bazıları ise olumsuz etkilediğini savunmuşlardır. Mesleki güvencenin öğretmenlerin performansını düşürdüğünü savunan bazı öğretmenler bu görüşlerini şu şekilde açıklamıştır: ö3: "Özelleşmekten yana değilim ancak güvencenin artık öğretmenler için zararlı olduğunu düşünüyorum. Yani ben 20 senelik öğretmenim geldiğim noktada yapsam da olur yapmasam da olur diyorum.", Ö4: "Hangi eğitim seviyesinde olursa olsun güvence vermek olumlu değil. Ancak temel hak ve özgürlükler öğretmene verilmeli. Mesleki başarı bekliyorsak hayat kaygısı düşürülmeli. Örneğin ekonomik kaygısı yüksek olursa para odaklı çalışır. Buda yapılan işin 
niteliğini düşürebilir. Verilen temel hak ve özgürlükleri iyi kullanan öğretmende başarılı oluyor ama kişisel çıkarları için kullananda var."

Tablo 4. Öğretmenlerin eğitim sistemindeki mesleki güvence uygulamaları ile okul çalışanlarının performansı arasındaki ilişki hakkındaki görüşleri

\begin{tabular}{|c|c|c|c|c|c|c|c|c|c|c|c|c|c|c|c|}
\hline & Ö1 & Ö2 & 0̈3 & 0̈4 & Ö5 & Ö6 & 0̈7 & Ö8 & Ö9 & 0̈10 & Ö11 & Ö12 & 0̈13 & Ö14 & f \\
\hline $\begin{array}{l}\text { Objektif bir } \\
\text { Performans } \\
\text { değerlendirmesi } \\
\text { olmadığı için } \\
\text { mesleki } \\
\text { güvence } \\
\text { çalışanlar } \\
\text { açısından çok } \\
\text { önemlidir. }\end{array}$ & $\checkmark$ & $\sqrt{ }$ & $\checkmark$ & & & & $\sqrt{ }$ & $\sqrt{ }$ & $\checkmark$ & $\sqrt{ }$ & $\sqrt{ }$ & $\sqrt{ }$ & $\sqrt{ }$ & $\sqrt{ }$ & 11 \\
\hline $\begin{array}{l}\text { Mesleki } \\
\text { güvence } \\
\text { objektif bir } \\
\text { performans } \\
\text { değerlendirme } \\
\text { ile } \\
\text { desteklenmiyor. }\end{array}$ & $\checkmark$ & & $\checkmark$ & $\checkmark$ & $\checkmark$ & $\sqrt{ }$ & & $\checkmark$ & $\sqrt{ }$ & & $\sqrt{ }$ & $\sqrt{ }$ & $\sqrt{ }$ & $\checkmark$ & 11 \\
\hline $\begin{array}{l}\text { Mesleki } \\
\text { güvence } \\
\text { performansı } \\
\text { düşürüyor. }\end{array}$ & & & $\checkmark$ & $\checkmark$ & V & & & & $\sqrt{ }$ & & & & & & 4 \\
\hline $\begin{array}{l}\text { Mesleki } \\
\text { güvence } \\
\text { performansı } \\
\text { pozitif etkiliyor. }\end{array}$ & $\checkmark$ & & & & & & $\checkmark$ & $\sqrt{ }$ & & $\sqrt{ }$ & $\sqrt{ }$ & & $\sqrt{ }$ & $\sqrt{ }$ & 7 \\
\hline $\begin{array}{l}\text { Performans } \\
\text { mesleki } \\
\text { güvence ile } \\
\text { değil iş ahlakı } \\
\text { ile ilgilidir }\end{array}$ & & V & & $\checkmark$ & & & & $\sqrt{ }$ & & $\sqrt{ }$ & $\checkmark$ & & & $\sqrt{ }$ & 6 \\
\hline $\begin{array}{l}\text { Mesleki } \\
\text { güvence } \\
\text { güdüleyici bir } \\
\text { performans } \\
\text { değerlendirme } \\
\text { ile anlamlıdır }\end{array}$ & $\checkmark$ & & $\checkmark$ & $\checkmark$ & $\sqrt{ }$ & $\sqrt{ }$ & & $\checkmark$ & $\checkmark$ & & $\checkmark$ & $\sqrt{ }$ & $\sqrt{ }$ & $\checkmark$ & 11 \\
\hline
\end{tabular}

Mesleki güvencenin performansı arttırdığını düşünen bazı katılımcılar ise görüşlerini şu şekilde ifade etmiştir: 0̈11: "Bana göre güvencesiz insan daha başarısız olur çünkü hep tedirgin. Rahat düşünemez, çalışamaz. Güvenceye sahip insan daha rahat düşünür daha üretken olur diye düşünmeliyiz"

Performansın mesleki güvence ile değil iş ahlakı ile ilgili olduğunu savunan bazı katılımcılar şunları söylemiştir: Ö10: "Yani güvence ile alakalı değil. işsini iyi yapma bilincine sahip olmak ve olmamak ile alakall. Bilinç önemli.",0̈4: "Mesleki ahlak önemli bir tarafta çok çalışan diğer tarafta yiyip içip oturan var ve aynı noktadasın ve aynı güvence ve şartlara tabisin." ö2: "Performans değerlendirmesi hissedilmeli yani içselleştirilmeli bence. Yani bu kişinin kişisel değerleri ile ilgili, kişilik özellikleri ile ilgili daha çok bence. Meslek ahlakı kavramı kişinin sahip olması gereken bir erdem olmalı. ".

Mesleki güvencenin güdüleyici bir performans değerlendirme ile anlamlı olacağına savunan bazı katılımcılar ise bu görüşlerini şu şekilde paylaşmıştır: Ö5: "Mesleki güvence sosyal devletin gereği olduğu kadar çalışanların görevlerini huzur ve güven içerisinde yapabilmeleri ve başkalarının kişisel baskılarına maruz kalmamaları için gereklidir ancak bunun çalışanları rehavete sevk etmemesi için çalışanları çalışmaya güdüleyecek onların performanslarını 
değerlendirecek ve ödüllendirecek sistemlere ihtiyaç vardır" ö1: "Eğer güvence verilmeden sadece performansa göre iş hakkı verilirse öğretmende "Iş̧imi kaybetmemek için her şeyi yaparım" düşüncesi olacaktır. Buda öğretmeni köleleştirir." demişleridir.

\section{5- Öğretmenlerin Türk Eğitim Sistemindeki Mesleki Güvence Uygulamalarına İlişkin Beklentileri}

Öğretmenlerin Türk Eğitim Sistemindeki mesleki güvence uygulamalarına ilişkin beklentileri Tablo $5^{\prime}$ te verilmiştir.

Tablo 5'e göre, öğretmenlerin Türk eğitim sistemindeki mesleki güvence uygulamalarına ilişkin beklentileri şunlardır; Çalışanın yaşam kaygısını engellemeli(6), İş güvencesi olmadan performans beklentisi köleleştirir(3), Mesleki güvence işin gereklerine göre belirlenerek verilmeli (4), Mesleki güvence sağlıklı performans değerlendirmesi ile birlikte olmalı(8).

Tablo 5. Öğretmenlerin Türk Eğitim sistemindeki mesleki güvence uygulamalarına ilişkin beklentileri

\begin{tabular}{|c|c|c|c|c|c|c|c|c|c|c|c|c|c|c|c|c|}
\hline & & Ö1 & Ö2 & 0̈3 & Ö4 & Ö5 & Ö6 & ö7 & Ö8 & Ö9 & Ö10 & ö11 & ö12 & Ö13 & Ö14 & $\mathbf{F}$ \\
\hline 1 & $\begin{array}{l}\text { Çalışanın yaşam } \\
\text { kaygısı iş } \\
\text { güvencesiyle } \\
\text { engellenmelidir }\end{array}$ & $\sqrt{ }$ & & & & & $\checkmark$ & $\sqrt{ }$ & $\checkmark$ & & & $\checkmark$ & $\sqrt{ }$ & & & 6 \\
\hline 2 & $\begin{array}{l}\text { Sadece performans } \\
\text { beklemenin } \\
\text { köleleştirici etkisine } \\
\text { karşı iş güvencesi } \\
\text { olmalıdır. }\end{array}$ & & & & & & & $\checkmark$ & & $\checkmark$ & $\checkmark$ & & & & & 3 \\
\hline 3 & $\begin{array}{l}\text { Mesleki güvence işin } \\
\text { gereklerine göre } \\
\text { yasayla düzenlenmeli }\end{array}$ & & & & $\checkmark$ & & $\checkmark$ & $\sqrt{ }$ & & & & & & & $\sqrt{ }$ & 4 \\
\hline 4 & $\begin{array}{l}\text { Mesleki güvence } \\
\text { sağlıklı performans } \\
\text { değerlendirmesi ile } \\
\text { birlikte olmalıdır. }\end{array}$ & & $\checkmark$ & $\checkmark$ & $\sqrt{ }$ & $\checkmark$ & $\checkmark$ & & $\sqrt{ }$ & $\checkmark$ & & & & $\checkmark$ & & 8 \\
\hline
\end{tabular}

Tablo 5'te verilen birinci tema ile ilgili olarak ö7: “Her an işten kovulacak ve sürgün edilecekmiş gibi hissetmemeli çalışan. Kendini rahatlıkla ifade edebilmeli insan. Yani fikirlerimizden ya da bir konu üzerinde fikir yürüterek yapılan tartışmalardan sorgulanmamalıyız.", Ö2: "Mesleki güvence öğretmenlerin performansını kesinlikle olumlu etkiler bence. Iş güvencesi olmalı. Sadece işine odaklanıyorsun, kaygıların azalıyor." şeklinde ifade kullanmışlardır. İkinci tema ile ilgili olarak Ö7: "Güvencenin olmadığı ortamda bizden istenenleri tam olarak yapanlar oluyoruz. Belli kalıplara sokuluyoruz." şeklinde ifade etmiştir. Üçüncü tema ile ilgili olarak ö14: "Öğretmen yetiştiriliyorsa eğittiği kişiye yeterli ve uygun eğitimi vermesi bile bir güvence. Öğretmen derse giriyor, öğrenci ile birebir iletişime giriyor, insan eğitiyor bu nedenle çok özel vasıfları olmalı. Ve ögretmen bu vasıfları aldığında da güvenceye sahip olmalı. Yani ben buradan mezun olacağım, öğretmen olarak atanacağım, çok iyi bir eğitim aldım bu bana güvence olarak verildi, maaşım olacak, sağlık, sosyal güvencem olacak diye düşünmeli öğretmen adayı. Bu şekilde mesleğini daha iyi benimseyecektir. ", 0̈4 : "Her okulun yapısı ve ihtiyaçları farklıdır, ihtiyaçlara göre kalite artırlmalı. Çalışmaya ve gelişime açık olmayan, masa başı çalışmak isteyen memur başka memuriyet kadrolarında çalıştırılmalı." şeklinde ifade kullanmışlardır. Dördüncü tema ile ilgili olarak Ö2: "Ben mesleki güvence ve performans değerlendirme dengesinin iyi ayarlanması gerektiğinin kesinlikle hayati olduğuna inanıyorum. Çünkü insanın sahip olması gereken temel haklar var. Bunlar toplumun varlığı için korunmalı. Örneğin Avrupa'da işsizlik maaşı veriliyor, nedeni ise toplum refahını korumak. Işsiz olan insanların suç işleyerek toplumun huzurunu bozabileceği düşünülerek onlara ücret ödeniyor. Toplumda geliri çok yüksek ve geliri düşük uçlar azaltılarak toplum refahı sağlanmaya çalışılıyor. Bizim ülkemizde de performansı yüksekse çok kazanır değilse işten atılır gibi bir uygulamada olmamalı" 


\section{SONUÇ TARTIŞMA VE ÖNERILER}

Son zamanlarda iş güvencesinin memurların performansını azalttığı yönünde çeşitli tartışmalar yer almaktadır. Ancak, iş güvencesi ilkesi, klasik yönetim kuramcılar arasında yer alan Max Weber'in bürokrasi kuramındaki memurluk kavramıyla (Bursalığlu, 2014; Öztekin, 1993) başlamış ve bu günkü modern yönetim anlayışını temsil eden insan kaynakları yönetiminde de yerini almıştır. Çünkü modern yönetim anlayışı örgütün sadece üretim boyutunu değil aynı zamanda insan ya da ilişki boyutunu dikkate almayı gerektirir. İnsan ya da ilişki boyutunu dikkate almak, bir bakıma çalışanların memnuniyetini, iş doyumunu, moralini, motivasyonunu ve işe bağlıı̆ını dikkate almaktır. Bu açıdan baktığımızda çalışanların stres ve kaygılarını azaltmada güvence büyük önem taşır. Bakan ve Büyükbeşe (2004) tarafından yapılan araştırma sonucunda elde edilen araştırma verileri iş güvencesi değişkeni ile motivasyon, genel tatmin, iş tatmini, sosyal tatmin arasında anlamlı ilişkiler olduğunu ortaya koymuştur. Bu araştırma sonucunda günümüzde kurumların en değerli varlığı olarak kabul edilen insan faktörünün kurum amaçları doğrultusunda en etkili şekilde yönlendirilebilmesi için kendilerine iş güvencesinin sunulması gerektiği, ancak iş güvencesinin yanında etkili bir performans değerlendirme sisteminin de yer alması gerektiği sonucuna ulaşılmıştır.

Mesleki güvence Illkesi ne ilişkin algıları konusunda bazı öğretmenler, " Güvence ilkesinin, ancak iş ahlakı ile birleşince iş kalitesinin oluşabileceğini, iş güvencesi eksikliğinin tek başına eğitimin kalitesini etkilemeyeceğini" ifade etmişlerdir. Aslında bu görüşü savunanlar öğretmenlik mesleğinin kendine has yönlerini vurgulamışlardır. Öğretmenlik mesleğinin bir sevgi işi olduğu, bu mesleği yürütmek için onu sevmek, insanları sevmek gerektiği ve bu özelliklerin öğretmenin sahip olması gereken kişisel özellikler arasında olduğu (Açıkgöz, 2003) belirtilmektedir. Ayrıca öğretmenin kendi yeterlik alanları ile ilgili öz değerlendirme yaparak kendi gelişimini sağlaması "kişisel ve mesleki değerler-mesleki gelişim" açısından sahip olması gereken bilgi beceri ve tutumlar arasında yer almaktadır (Aslan, 2011).

Araştırmaya göre öğretmenlerin bazıları güvence ilkesini, hakların yasalarla korunması, sosyal devlette sosyal güvenlik unsuru ve hatta bir yaşam hakkı olduğunu ifade etmişlerdir. Güvence ilkesi bir yönüyle de sosyal devlet anlayışının ve insan haklarının bir sonucudur. Kara (2009) tarafından yapılan çalışmada sosyal devletin vatandaşların temel intiyaçlarının karşılanması açısından gerekli olduğu sonucuna varıımışıı. Çünkü liberal düzenin getirdiği yoksullaşma ve artan işsizlik, sonucunda İnsanlar, Maslow'un intiyaçlar hiyerarşisinde belirttiği en temel gereksinimlerini bile karşılamaktan yoksun kalabilmektedir. Dünyada başgösteren coronavirüs salgını dolayısıyla işini kaybeden milyonlarca insanın çaresiz bir şekilde sokaklara atılması ve yaşanan insani dram sosyal devlete olan gereksinimi açıç̧a ortaya koymuştur. Zorlutuna (2012) tarafından yapılan araştırma sonucunda da iş güvencesinin günümüzde, birçok çalışanın ücret veya diğer beklentilerinden daha önemli bir konu haline geldiğine işaret ettiği görülmektedir.

Bazı öğretmenler ise güvence ilkesinin, çalışanlara psikolojik rahatılı getirdiğini ve çalışanlarda informal etkilere karşı direnç sağladığını belirtmişlerdir. Çalışanlar, yasalar tarafından yeterince korunmadıklarını hissettiklerinde üstlerinin ya da erki elinde bulunduran siyasilerin yasal olmayan talep ve baskıları karşısında kendilerini zayıf hissederek meşru olmayan yollara girebilirler. Max Weber'in memurları mesleki yaşamları boyunca güvenceye almaya çalışmasının asıl nedeni budur. Bazı katııımcılar güvencesizliğin onlar üzerinde baskı ve gerilim yaratacağını, işini kaybetme korkusunun, iş tatminini engelleyeceğini belirtmişlerdir. Karacaoğlu (2015) tarafından yapılan araştırma ya göre, çalışanların algıladıkları iş güvencesizliği arttıkça çalışanların işten ayrılma niyetlerinin de arttığı görülmektedir.

Bazı katııımcılar Türk eğitim sisteminde uygulanan güvence ilkesinin kurum açısından ve çalışanlar açısından olumlu yönleri olduğunu belirtmişlerdir. Kurum açısından olumlu yönleri arasında "Iş̧in kalitesini, işe aidiyet duygusunu artırdığını, örgütte psikolojik gerilimi ve sorunları azalttığını, performansı, güven hissini, iş motivasyonunu artırdığını" belirtmişlerdir. Çağdaş 
eğitim yönetiminde işin kalitesini artırımanın yanında işe ve kuruma bağlıık, kurumla bireyler ya da çalışanlar arasına güvene dayalı ilişkiler kurma ve çalışanların çalışmaya motive edilmesi önemli hedefler arasında yer almaktadır (Aydın, 2014). Mesleki güvence, bilimsel esaslara dayalı bir ödüllendirme sistemi ile desteklendiğinde çağdaş yönetim anlayışının kalite hedefleri arasında yer alan çalışanların memnuniyetini (Kavrakoğlu, 1998; Kayıkçı, 1999), takım çalışmasını, iş doyumunu, moral ve motivasyon unsurlarını sağlamaya ortam hazırlar.

Ancak araştırmaya göre Türk eğitim sisteminde uygulanan güvence ilkesinin kurum ve çalışanlar açısından bazı olumsuz yönlerinin de olduğunu göstermiştir. Kurumsal açıdan olumsuz görülen yönler "Kişide kaygısızlığa yol açıı̆ı, örgüte işin niteliğini düşürdüğü ve kurumda monotonluğu artırdığı, sağladığı psikolojik rahatlama ile işin kalitesini düşürdüğü" belirtilmiştir. Çalışanlar açısından neden olduğu olumsuz yönler ise, "Çalışanda adalet duygusunu negatif etkilediği, kişide tükenmişlik hissini artırdığı, kurumda negatif ilişkilere ve mutsuzluğa neden olduğu" şeklinde ifade edilmiştir. Buna göre kurumsal açıdan baktığımızda sadece mesleki güvence sağlamanın çalışanlarda kaygısızık ve psikolojik rahatlama yarattığını ancak bunun tek başına olduğunda işin kalitesini düşürmekle kalmadığını aynı zamanda kurumda monotonluğa yol açtığını göstermektedir. Ödül ceza ve diğer güdüleyici unsurların eksiklikleri sonucunda zamanla insanların gelişim hedefleri ve yenileşme hedefleri taşımamaları ve monotonlaşma sonucunda insanların tükenmişlik ve mutsuzluk hissine kapılmaları güvence ilkesinin uygun şekilde işletilmemesinden kaynaklanmaktadır, bunu vurgulayan bazı katılımcılar ise "Mesleki güvence güdüleme ile orantılı olmalı" şeklinde görüş bildirerek ödül, ceza, performans değerlendirme gibi çalışanları güdüleyecek unsurların olması gerektiğini savunmuşlardır. Aynı şekilde bazı araştırmalar (Sabancı,1998; Sarpkaya, 2006; Koçak, 2002; Ünal, 2000) Türk Eğitim Sisteminde okullarda kullanılan ödüllendirme sisteminin öğretmenleri güdülemede yetersiz kaldığını göstermektedir. Aydın (2012) tarafından yapılan çalışma da bürokrasinin ilgili bütün taraflarının, bürokrasinin işleyişinden şikâyetçi olduğu ve memurların keyfi olarak işi yavaşlattıklarına önemli ölçüde kanaat getirdiği sonucuna varıldığı görülmektedir.

Katılımcıların büyük çoğunluğu eğitim sisteminde performans değerlendirmesi yapılmadığını ya da yapılıyor olsa bile objektif bir şekilde yapılmadığını belirtmişlerdir. Mesleki güvencenin performans üzerindeki etkisi konusunda ise farklı görüşlere rastlanmıştır. Bazı katılımcılar mesleki güvencenin performansı düşürdüğünü, bazıları ise arttırdığını savunurken katıımcıların önemli bir bölümü ise Performansın mesleki güvence ile değil iş ahlakı ile ilgili olduğunu öne sürmüşlerdir. Bazı katılımcılar ise, mesleki güvencenin güdüleyici bir performans değerlendirme ile anlamlı olacağını düşünmüşlerdir. Türk eğitim sisteminde iç ve dış güdüleyicilerden yoksun bir güvence ilkesinin uygulandığı ve gerek çalışanlar gerekse örgütün verimliliği açısından önemli sorunlar yaşandığı görülmektedir. Bunun en önemli nedenleri arasında güdüleyici ve ödüllendirici bir performans değerlendirme sisteminin olmaması söylenebilir. Bu nedenle güdüleme veya motivasyon, örgüt yönetimlerinin çalışanların işe devamı, işte sürekliliği ve performans düzeyini artırma açısından önemle üzerinde durdukları bir konudur (Sabancı, 1998, s. 45). Hizmet ve endüstri işletmelerinde yapılan bir araştırmaya göre (Örücü ve Kanbur, 2008) örgütsel-yönetsel motivasyon uygulamalarının verimlilik üzerinde etkisi olduğu ancak performans üzerinde böyle bir etkisinin görülmediği sonucuna ulaşılmıştır. Araştırmalar performans değerlendirmesinin insan kaynakları yönetiminde, çoğunlukla ücret ve maaş yönetimi, performans hakkında geri bildirim ve çalışanların zayıf ve güçlü yönlerinin tespitinde kullanıldığını göstermektedir (Özgen ve Yalçın, 2010, s. 217). Bakan ve Kelleroğlu (2003) tarafından yapılan araştırmada çalışanların işteki verim ve mesleki bilgi düzeyleri esas alınarak, personel tarafından kabul görerek yapılan performans değerlendirmesinin faydalı olacağı sonucuna varıldığı görülmektedir. Mercin (2005) içinde geliştirme işlevi yer alan İnsan kaynakları yönetimi bölümü özel eğitim kurumlarında yer alırken kamu kurumlarında bu bölümün olmadığını saptamıştır. Hâlbuki başarı için iş görenlerin hangi kurumda olursa olsun önemsenmesi, ihtiyaçlarına cevap verilmesi gerekmektedir. Bu gereksinim yüzyılımızın vazgeçilmez bir olgusu olduğu anlaşılmaktadır. 
Bu durumda çalışanların çalışmaya güdülenmesini sağlayacak stratejilerin (Aydın, 2014) hayata geçirilmesi gereklidir. Bunun için bilimsel ve objektif kıstaslara dayalı bir performans değerlendirme sisteminin uygulamaya konması çalışanların takdir edilmesi ve çalışanların monoton giden bir süreci yok edecek ve çalışanların önünde hedefler koymalarını sağlayacak ödül ve terfi sistemleri devreye sokulmalıdır. Diğer yandan güvencesiz işin meslek olması güçleşebilir, mesleki bir kimliği olan iş, güvenceli olmaya daha yatkındır. O halde öğretmenlik işini mesleğe dönüştürmede etkili olabilecek avukatlardaki Baro, doktorlardaki Tabipler Birliği gibi meslek örgütlerine (Toprakçı, 2009; Toprakci. Bozpolat ve Buldur 2010) ihtiyaç olduğunu da belirtmek gerekir.

\section{KAYNAKÇA}

Açıkgöz, K. Ü. (2003). Etkili öğrenme ve öğretme. İzmir: Kanyılmaz Matbaası.

Aslan, H. (2011). Sınıf yönetiminin temel kavramları. Ankara: İhtiyaç Yayınları.

Aydın, N. (2012). Weberyen Bürokraside Liyakat ve Türk Kamu Bürokrasisinden Bir Kesit: Siyasetin Bürokrasi İronisi. Sayıştay Dergisi (85), 51-67.

Aydın, M. (2013). Eğitimde örgütsel davranış. Ankara: Gazi Kitabevi.

Aydın, M. (2014). Eğitim yönetimi. Ankara: Gazi Kitabevi.

Bakan, I., \& Büyükbeşe, T. (2004). Çalışanların Iş̧ Güvencesi ve Genel İş Davranışları Ilişkisi: Bir Alan Çalışması. Erciyes Üniversitesi Iktisadi İdari Bilimer Fakültesi Dergisi, 23, 35-39.

Bakan, İ., \& Kelleroğlu, H. (2003). Performans Değerlendirme: Çalışanların Performansı Değerlendirme Uygulamalarından Beklentileri Konusunda Bir Alan Çalışması. Süleyman Demirel Üniversitesi iktisadi ve Idari Bilimler Fakültesi Dergisi, 8(1), 103-127.

Bilgin, K. U. (2011). Insan kaynakları yönetimi ve Türk kamu personel sistemi. Ankara: TODAiE Yayınları. Bursalıoğlu, Z. (2014). Eğitim yönetiminde teori ve uygulama. Ankara: Pegem Akademi.

Can, H. (2001). Kamu ve özel kesimde insan kaynakları yönetimi. Siyasal Kitabevi.

Creswell, J. W. (2014). Researchdesign. qalitatative, qantiative and mixed methods approaches . Lincoln: Sage Publications.

Çakır, Ö. (2007). İ̧ini Kaybetme Kaygısı: İ̧̧ Güvencesizliği. Çalışma ve Toplum, 1, 117-140.

Dede, E. (2017). İ̧̧ Güvencesizliği Algısının ve Örgütsel Güven Düzeyinin Örgütsel Vatandaşıık Davranışı Üzerindeki Etkileri: Devlet Ortaokulu ve Özel Ortaokul Öğretmenleri Üzerine Bir Araştırma. Doktora Tezi. İstanbul Ticaret Üniversitesi Sosyal Bilimler Enstitüsü.

Demirtaş, H., \& Güneş, H. (2002). Eğitim yönetimi ve denetimi sözlügü. Malatya: Anı Yayıncılık.

Devlet Memurları Kanunu. (1965). (12056). T.C Resmi Gazete.

Dığın, Ö. (2008). İnsan Kaynakları Yönetiminde İş Güvencesi ve Konuyla İlgili Yapılan Bir Araştırma. Yüksek Lisans Tezi. Edirne: Trakya Üniversitesi Sosyal Bilimler Enstitüsü.

Edmonds, W. A., \& Kennedy, T. D. (2017). An applied guide to research designs: quantitative, qualitative, and mixed methods. Sage Publications.

Eren, V. (2006). Personel Rejiminde Bürokratik Modelden Işletmeci Anlayışa Geçiş. Sosyal Ekonomik Araştırmalar Dergisi, 6(11), 130-154.

Eroğlu, T. (2010). Yeni Kamu Yönetimi Anlayışının Türk Kamu Personeli Yönetimine Etkisi. ZKÜ Sosyal Bilimler Dergisi, 6(12), 225-233.

Greenhalgh, L., \& Rosenblatt, Z. (1984). Jobinsecurity: Toward Conceptual Clarity, Academy of Management Review. 9(3), 438-448.

Kara, B. (2009). Sosyal Devletten Küresel Devlete: Türkiye'de Kamu Çalışanları ve Temel Haklar. Süleyman Demirel Üniversitesi iktisadi Idari Bilimler Fakültesi Dergisi, 14(1), 369-386.

Karacaoğlu, K. (2015). Çalışanların İ̧̧ Güvencesizliğinin İşten Ayrılma Niyetleri Üzrindeki Etkisi: Alanya Bölgesindeki Beş Yıldızı Otellerde Bir Araştırma. Uluslararası Alanya Işletme Fakültesi Dergisi, 7(1), 13-21.

Kavrakoğlu, İ. (1998). Toplam Kalite Yönetimi. İstanbul: Kal-Der Yayını.

Kayıkçı, K. (1999). Toplam Kalite Yönetiminde Liderlik. Kuram ve Uygulamada Eğitim Yönetimi, 5, 15-25.

Kayıkçı, K. (2013). Türkiye'de Kamu ve Eğitim Alanında Sendikalaşma ve Öğretmen Ile Okul Yöneticilerinin Sendikalardan Beklentileri. Amme Idaresi Dergisi, 46(1), 99-126.

Kayıkçı, K., Özdemir, İ., \& Özyıldııım, G. (2015). Illk Defa ve Yeniden Okul Müdür Görevlendirmesi, Sözlü Sınav Üzerine Bir Değerlendirme. Kuram ve Uygulamada Eğitim Yönetimi, 12(4), 471-498. 
Koçak, Y. (2002). İlköğretim okullarında öğretmen motivasyonu. Yayınlanmamış yüksek Lisans Tezi. Ankara: Gazi Üniverstesi Eğitim Bilimleri Enstitüsü.

Landis, J. R., \& Koch, G. G. (1977). The Measurement of Observer Agreement For Categorical. Data Biometrics, 33, 159-174.

Mercin , L. (2005). İnsan Kaynakları Yönetimi'nin Eğitim Kurumları Açısından Gerekliliği ve Geliştirme Etkinliği. Elektronik Sosyal Bilimler Dergisi, 4(14), 128-144.

Mills, G. E. (2003). Action Research: A guide for the teacher researcher (2nd ed.). New Jersey: Merrill PrenticeHall.

Örücü, E., \& Kanbur, A. (2008). Örgütsel-Yönetsel Motivasyon Faktörlerinin Çalışanların Performans ve Verimliliğine Etkilerini İncelemeye Yönelik Ampirik Bir Çalışma: Hizmet ve Endüstri İşletmesi Örneği. Yönetim ve Ekonomi, 15(1), 85-97.

Özgen, H., \& Yalçın, A. (2010). Insan kaynakaları yönetimi stratejik bir yaklaşım. Adana: Nobel Kitabevi.

Öztekin, A. (1993). Idareye giriş. Malatya: Yenimalatya Basım Yayın.

Patton, M. Q. (2001). Qalitative research \& evalution methods. ThousandOaks: Sage Publications.

Sabancı, A. (1998). Güdüleme Düzeni Açısından Türk Milli Eğitim Örgütünde Mevcut Ödül ve Terfi Sistemine Bir Bakış. Çağdaş Eğitim, 23(240), 45-48.

Sabuncuoğlu, Z., \& Tüz, M. (1995). Örgütsel psikoloji. Bursa: Ezgi Kitabevi.

Sarpkaya, R. (2014). Türk eğitim sistemi ve okul yönetimi. Ankara: Anı Yayıncılık.

Seçer, B. (2007). Kariyer Sermayesi ve İstihdam Edilebilirliğin İş Güvencesizliği Üzerindeki Etkisi. Doktora Tezi. İzmir Dokuz Eylül Üniversitesi Sosyal Bilimler Enstitüsü Çalışma Ekonomisi ve Endüstri İlişkileri Anabilim Dalı.

Taşkent, Ş. (2002). Uluslararası Hukukta İşçinin Feshe Karşı Korunması. Iktisadi Sosyal ve Uluslararası Hukuki Boyutu Ile Iş̧̧̧inin Feshe Karşı Korunması Sempozyumu (s. 63-76). İstanbul Barosu Yayınları.

Tortop, N., Aykaç, B., Yayman, H., \& Özer, M. A. (2007). Insan kaynakları yönetimi. Ankara: Nobel Yayın Dağıtım.

Toprakçı, Erdal (2009) Öğretmenlerin Suç Karnesi- Yargı Kararlı Gazete Haberleri Ölçütünde Karşılaştırmalı Bir Analiz Denizli: Pamukkale Üniversitesi Eğitim Fakültesi, IV.Ulusal Eğitim Yönetimi Kongresi, Bildiri Kitabı, 14-15 Mayıs 2009 (ss.475-487) Online: https://www.erdaltoprakci.com.tr/wpcontent/uploads/2020/05/suc-karnesi.pdf

Toprakçı, E., E.Bozpolat ve S.Buldur (2010) Öğretmen Davranışlarının Kamu Meslek Etiği Illkelerine Uygunluğu e international journal of educational research Volume: 1 Issue: 2 Autumn 2010 pp.35 50 http://static.dergipark.org.tr/article-download/imported/1073000034/1073000025.pdf

Toprakçı, Erdal, Ilknur Çakırer, Asuman Bilbay, Esen Bagcivan, Ilkay Bayraktutan (2010) Kuram ve Uygulamada Eğitim Denetmenleri Meslek Etiği Eğitimde Politika Analizleri ve Stratejik Araştırmalar Dergisi Volume 5, Number 1 January 2010 ss.14-

23 http://www.inased.org/epasad/v5n1/EPASADv5n1.pdf

Tunçer, P. (2013). Örgütlerde Performans Değerlendirme ve Motivasyon. Sayıştay Dergisi, 88, 87-108.

Ünal, S. (2000). İlköğretim Okulu Yöneticilerinin Okullarında Motivasyonu Sağlama Etkinlikleri. Pamukkale Üniversitesi Eğitim Fakültesi Dergisi, 1(7), 1-8.

Yıldırım, A., \& Şimşek, H. (2013). Sosyal Bilimlerde Nitel Araştırma Yöntemleri. Ankara: Seçkin Yayıncılık. Yüksel, Ö. (1997). Insan kaynakları yönetimi. Ankara: Volkan Matbaacılık.

Zorlutuna, E. (2012). Bir İşletmede Kadrolu Çalışanlar ile Taşeron Çalışanların İş Tatmini ve Motivasyon Değişkenleri Arasındaki İlişkinin İncelenmesi. Yüksek Lisans Tezi. Maltepe Üniversitesi Sosyal Bilimler Üniversitesi. 


\section{The Effect of Occupational Assurance Practices on School and the Performance of Teachers in the Turkish Education System}

\author{
Arzu Engür \\ Antalya Provincial Directorate of National \\ Education -Turkey \\ arzuengur@hotmail.com
}

\author{
Prof. Dr. Kemal Kayıkçı \\ Akdeniz University-Turkey \\ kemalkayikci@akdeniz.edu.tr
}

\begin{abstract}
Assurance principle is one of the important principles of human resources management. Assurance is divided into two as job security and authority. Job security means that the individual cannot be fired without justified reasons. It can be said that job security, job satisfaction, morale and performance concepts affect each other. This study basically aims to examine the effects of social and psychological dimensions of the job security concept handled by different disciplines on employees and their organizations from a human resources management perspective. Qualitative research method was used in the research. In the study, which was designed with a scientific study, which is one of the qualitative research methods, the data were collected through a semi-structured interview form and analyzed by content analysis technique. As a result of the research, it is stated that the quality of the work is not related to professional assurance, but to the work ethic that the person has, but it should be stated that there should be professional assurance. It is stated that the absence of professional security will create psychological pressure, it is stated that professional security should be accompanied by a healthy performance assessment, professional security reduces anxiety and contributes to the employees to work in an environment of peace and tranquility. On the other hand, it is stated that excessive and unconditional job security decreases the quality of work in the organization, increases the monotony and sense of burnout in the organization and causes anxiety in the employee. It is stated that performance awareness should be provided, training should be given, performance evaluation should be a fair, objective evaluation with expert staff and multi-criteria performance evaluation should be made.
\end{abstract}

Keywords: Teacher, Human Resource, Performance, Professional assurance

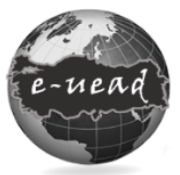

E-International Journal of Educational Research, Vol: 11, No: 2, 2020, pp. 16-34

DOI: 10.19160/ijer.735585

Received: 2020-05-11 Accepted: 2020-09-04

\section{Suggested Citation:}

Engür, A. \&. Kayıkçı, K. (2020). The Effect of Occupational Assurance Practices on School and the Performance of Teachers in the Turkish Education System, E-International Journal of Educational Research, Vol: 11, No: 2, 2020, pp. 16-34, DOI: 10.19160/ijer.735585 


\section{EXTENDED ABSTRACT}

Problem Assurance principle is one of the important principles of human resources management. Assurance is divided into two as job security and authority. Job security refers to the fact that the person is not fired without a just cause and authority guarantee refers to the person's ability to maintain his position in the office where he is promoted. Civil servant is perceived as a only job security in Turkey, an objective performance evaluation and based reward and penalty system not working well and consequently, it causes criticisms of inefficiency in public and educational administration. Besides the principle of assurance, using the reward, motivating the training staff to work and it plays an important role in increasing the performance required to keep the organization alive. In this study, teachers' job security applied to civil servants, the opinions of the occupational assurance applied on the performance, the psychology of the employees and the organization have been tried to be determined.

The aim of this study is to reveal the effect of the assurance principle applied in the Turkish education system on the teacher and the organization and to offer suggestions for more effective functioning. For this purpose, the opinions of the teachers about the professional security applied to civil servants, the performance of the applied professional security on the psychology of the employees and the organization were tried to be determined. In the research, answers to the following questions were sought:

1- What are the perceptions of teachers regarding the concept of professional security?

2- What are the opinions of the teachers regarding the positive aspects of the professional assurance principle applied in the education system?

3- What are the opinions of the teachers regarding the negative aspects of the professional assurance principle applied in the education system?

4- What are the opinions of teachers about the effect of professional assurance practices in the Turkish education system on teachers' performance?

5- What are the expectations of teachers regarding occupational assurance practices in the Turkish Education System?

Method: Qualitative research method was used in the research. It was designed with a case study of qualitative research methods. In the research, the data were collected through a semistructured interview form and analyzed by content analysis technique. The study group of the study was selected among the teachers working in secondary schools in central districts of Antalya province. Maximum diversity sampling was used to determine the study group. interviews were made with 14 teachers working in secondary education. The interviews were held face to face. Interviews were recorded by voice recording and supported by note-taking method. In the analysis stages, content analysis and descriptive analysis were performed using NVIVO 10 qualitative research package program.

Findings: Some teachers stated that "the principle of assurance, when combined with work ethic, can only occur in the quality of work and the lack of job security will not affect the quality of education". Some teachers, on the other hand, assured that the principle of assurance brings psychological comfort to employees and stated that it provides resistance to informal effects in employees. Psychological relaxation allows employees to stay away from tension and so it can make it better in terms of morale and job satisfaction. It can also strengthen the resilience or tendency to enforce the law against the private or inappropriate (illegal) demands of supervisors or external pressures. Positive aspects of the assurance policy applied according to the participants for the institution defined as; "Increasing the quality of work, sense of belonging, reducing 
psychological tension and problems in the organization, increase performance, sense of trust, motivation of work"

According to the participants, as the positive aspects of the principle of assurance for the employees, it has been stated that the employees will feel safe, increase their job satisfaction, make the relations sincerely, affect the education of teachers positively, and the lack of professional security will create psychological pressure. However, some participants stated that professional assurance and motivation factors should be proportional. According to the participants, providing professional assurance for the Institution creates anxiety and psychological relief for the employees and it causes monotony in the institution. the negative consequence for employees is that the sense of justice is negatively affected. The most important reason for this is that the difference between many employees and little or no employees is not determined and people are not appreciated for their work. According to the opinions of teachers about the effect of professional assurance practices in the Turkish education system on teachers' performance, The vast majority of participants did not evaluate performance in the education system or even if they are being done, they stated that they are not done objectively.

According to the results of the research, it is thought that the quality of the work is not related to professional assurance, but to the work ethic of the person. however, it is stated that there should be professional security. It is said that the absence of professional security will create psychological pressure and that professional security should be together with a healthy performance assessment. It is stated that professional security reduces anxiety and contributes to employees working in an environment of peace and tranquility. However, excessive and unconditional job security is said to decrease the quality of work in the organization and cause monotony in the organization. It is stated that it increases the sense of burnout in the employee and causes anxiety in the employee. It is stated that performance awareness should be provided, training should be given, performance evaluation should be a fair, objective evaluation with expert staff and multi-criteria performance evaluation should be made. In line with the findings and conclusions obtained from the research, it may be suggested to carry out studies to protect the assurance principle and take measures to measure the performance of the employees. 